\title{
T-helper cell polarisation following severe polytrauma
}

\author{
HDT Torrance ${ }^{1,2,3^{*}}$, K Brohi $^{2,3}$, G Warnes ${ }^{2}$, HC Owen ${ }^{1}$, CJ Hinds ${ }^{1,3}$, DJ Pennington ${ }^{2}$, MJ O'Dwyer ${ }^{1,3}$ \\ From ESICM LIVES 2015 \\ Berlin, Germany. 3-7 October 2015
}

\section{Introduction}

Severe polytrauma induces an immunosuppressive response and is associated with a very high incidence of nosocomial infections. Previous studies have inferred that this detrimental immune response results from polarisation of the $T$ helper $\left(T_{h}\right)$ response towards an anti-inflammatory, $\mathrm{T}_{\mathrm{H}} 2$ dominated, response at the expense of a bactericidal, $\mathrm{T}_{h} 1$ response [1].

\section{Objectives}

1) To define alterations in $T_{H}$ cell subsets following severe blunt polytrauma.

\section{Methods}

Patients presenting to the emergency department within 2 hours of severe polytrauma were eligible if intubated either at the scene or in ED. Isolated head injuries and those not expected to survive 24 hours were excluded.
EDTA anti-coagulated blood was drawn at 0hr (within 2 hours of injury), at 24 and $72 \mathrm{hrs}$. Samples were immediately lysed, washed, stained and analysed using a standardised human 8-colour $\mathrm{T}_{\mathrm{H}} 1,2 \& 17$ panel [2] on an LSR II flow cytometer. A paired white cell count differential was obtained at each sampling point. Patients were followed until discharge or death. Data were analysed using non-parametric statistics, with results presented as median and IQR.

\section{Results}

15 consecutive severe polytrauma patients requiring Intensive Care Unit (ICU) admission were recruited. Demographic and clinical data are outlined in Figure 1. Twelve (80\%) lymphocytosis $\left(3.3 \times 10^{9} / \mathrm{L}, 2.5-4.4 \times 10^{9} / \mathrm{L}\right)$ (Figyre 2A). At 72 hours leukocytes had fallen $(P<0.01$, figure $2 \mathrm{~A}$ ) such that $6(54 \%)$ of those surviving were lymphopenic $\left(0.9 \times 10^{9} / \mathrm{L}, 0.6-1.2 \times 10^{9} / \mathrm{L}\right)$. Circulating

\begin{tabular}{|c|c|c|}
\hline & Table 1. Patient demographics & \\
\hline & Age & $33(22-59.25)$ \\
\hline & Male & $9(60 \%)$ \\
\hline & Scene systolic BP & $95(56-127)$ \\
\hline & Admission $\mathrm{pH}$ & $7.15(7.00-7.29)$ \\
\hline & Admission BD & $8.1(4.3-19)$ \\
\hline & ISS & $38(29-51)$ \\
\hline & Blunt Injury & $12(80 \%)$ \\
\hline & PRBCs transfused over first $24 \mathrm{hrs}$ & $15(5-22)$ \\
\hline & 28 day mortality & $7(47 \%)$ \\
\hline & $\begin{array}{l}\text { BP, Blood pressure; } B D, \text { Base deficit; } \\
\text { over first } 24 \text { hours. Data expressed as }\end{array}$ & $\begin{array}{l}\text { Packed Red Blood Cell transfiusions } \\
\text { number and percentage. }\end{array}$ \\
\hline Figure 1 & & \\
\hline
\end{tabular}

${ }^{1}$ Barts \& the London School of Medicine, QMUL, William Harvey Research

Institute, London, United Kingdom

Full list of author information is available at the end of the article

(c) 2015 Torrance et al.; This is an Open Access article distributed under the terms of the Creative Commons Attribution License (http:// creativecommons.org/licenses/by/4.0), which permits unrestricted use, distribution, and reproduction in any medium, provided the original work is properly cited. 

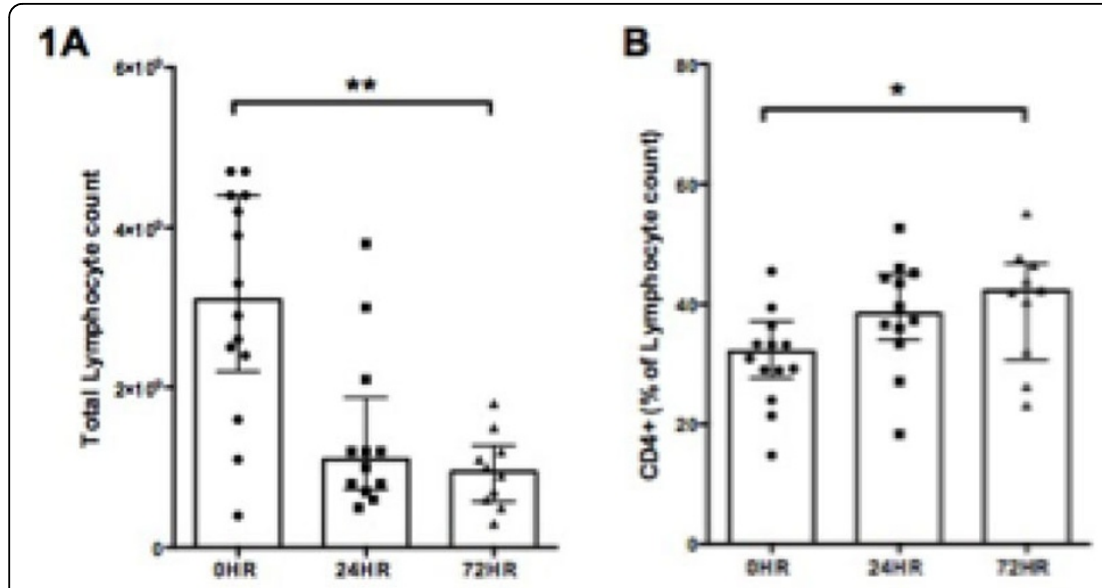

C

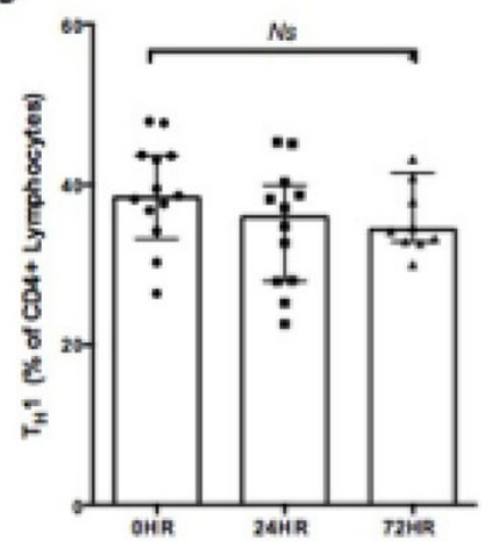

D

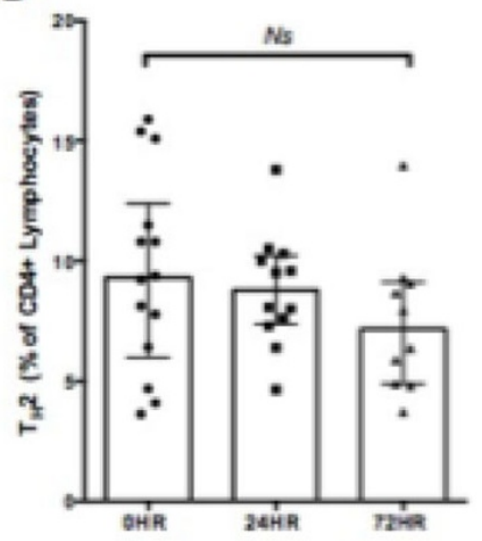

E

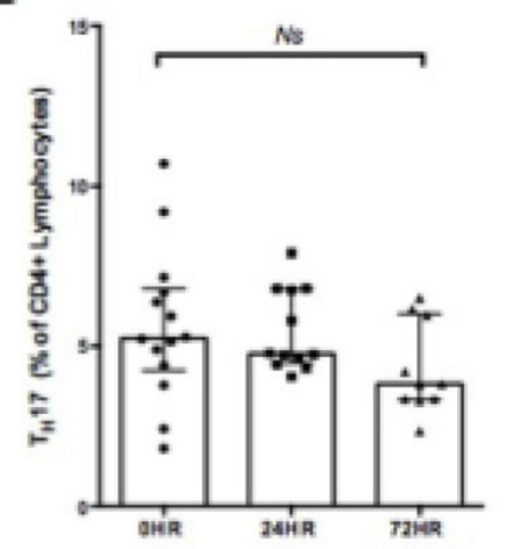

Figure 2

$\mathrm{CD}^{+}(P=0.01$; Figure $2 \mathrm{~B})$ and $\mathrm{CD} 4^{+} \mathrm{CD} 25^{+}(P<0.05)$ lymphocytes increased over 72 hours. When expressed as a percentage of total circulating lymphocytes no significant change in the proportions of the $\mathrm{T}_{\mathrm{H}} 1,2 \& 17$ subpopulations was detected (Figure 2C-E).

\section{Conclusions}

Severe polytrauma patients swiftly become lymphopenic. Although a failure to normalise this during the ICU stay correlates with higher mortality [3] our study of $\mathrm{T}_{\mathrm{H}}$ cell subtypes demonstrates no evidence of a switch to a detrimental anti-inflammatory $\mathrm{T}_{\mathrm{H}} 2$ subtype at the expense of the potentially protective bactericidal $\mathrm{T}_{\mathrm{H}} 1$ subtype.

\section{Grant Acknowledgment}

Royal College of Surgeons of England, Barts \& the London Charity.

\section{Authors' details}

${ }^{1}$ Barts \& the London School of Medicine, QMUL, William Harvey Research Institute, London, United Kingdom. ${ }^{2}$ Barts \& the London School of Medicine, QMUL, Blizard Institute, London, United Kingdom. ${ }^{3}$ Barts Health NHS Trust,

Trauma \& Critical Care, London, United Kingdom.

Published: 1 October 2015

\section{References}

1. Marik PE, Flemmer M: The immune response to surgery and trauma: Implications for treatment. J Trauma Acute Care Surg 2012, 73:801-8.

2. Maecker HT, et al: Standardizing immunophenotyping for the Human Immunology Project. Nat Rev Immunol 2012, 12:191-200.

3. Heffernan DS, et al: Failure to normalize lymphopenia following trauma is associated with increased mortality, independent of the leukocytosis pattern. Crit Care 2012, 16:R12.

doi:10.1186/2197-425X-3-S1-A848

Cite this article as: Torrance et al:: T-helper cell polarisation following severe polytrauma. Intensive Care Medicine Experimental 2015 3(Suppl 1): A848. 